\section{LOCAL MEDICAL SOCIETIES}

\section{MANCHESTER MEDICAL SOCIETY}

At a joint meeting of the Sections of Medicine and Pathology on January 12 Professor C. H. Gray gave an account of "Some Clinical Studies of Urinary Adrenal Steroids."

He said that although there was evidence that the physiologically important hormones secreted by the adrenal gland were hydrocortisone, corticosterone, aldosterone, and two androgens, a very much larger number of substances chemically related to these were excreted in the urine. Some might perhaps be intermediates in the synthesis of the important steroids in the adrenal gland which had leaked out in small quantities. Others, however, were metabolites of the active hormones. It was small wonder, therefore, that the earlier methods of determining adrenocortical steroid hormones in urine had been unsatisfactory, either because of lack of specificity or because they estimate some functional group common to a number of metabolites. Separation and estimation of all the adrenal metabolites in urine was necessary for a complete picture but would tax the time and energy of a mammoth institute.

\section{Hormone Assays in Endocrine Disorders}

The estimation of cortisone, hydrocortisone, and tetrahydrocortisone by paper chromatography seemed to be of value in the diagnosis of hypoadrenalism, continued Professor Gray, although these three metabolites accounted for only an extremely small fraction of endogenous or exogenously administered adrenal hormones. In both Addison's and Simmonds's diseases the excretion of these three compounds was greatly reduced, and might not be measurable in many patients with the former disease. In Simmonds's disease administration of A.C.T.H. restored the excretion to normal limits. The appearance of hydrocortisone in the urine after administration of cortisone, and of cortisone after administration of hydrocortisone, to patients with Addison's disease or after adrenalectomy showed that hydrocortisone and cortisone were freely interconvertible in the body even in the absence of the adrenals. The proportions of cortisone, hydrocortisone, and tetrahydrocortisone in the urine were approximately the same whichever hormone was administered. There was no doubt that cortisone and hydrocortisone were therapeutically equivalent, except possibly when some local action was required, as with some ophthalmological and joint conditions.

Some, but not all, cases of Cushing's disease showed an increased excretion of hydrocortisone, cortisone, and tetrahydrocortisone. When the total excretion of these three compounds was within normal limits, the excretion of either cortisone:or hydrocortisone might be increased, suggesting that delayed inactivation of the active hormones might sometimes be an important factor in Cushing's disease. In other cases, however, none of these metabolites was increased, and, while it was possible that in these the adrenocortical hormones might be metabolized to a greater extent via other pathways, it was not impossible that in this disease phases of normal activity and of overactivity of the adrenal gland might alternate. Perhaps hypersensitivity of the tissues also played some part.

The excretion of cortisone, hydrocortisone, and tetrahydrocortisone was not increased during salicylate therapy, so that unless there was an alteration of the metabolism of the adrenocortical hormone from normal it seemed unlikely that salicylates produced their therapeutic effect by stimulating the pituitary adrenal axis.

North of England Obstetrical and Gynaecological Society

At the annual general meeting in Manchester on January 21 the following officers were elected for 1955: President, Mr. H. J. Malkin (Nottingham); hon. treasurer, Mr. C. H. WALSH (Liverpool); hon. general secretary, Mr. J. B. COCHRANE (Nottingham); hon. reporting secretary, Miss U. M. LISTER (Leeds).
Nova et Vetera

\section{THE ILLNESS OF EDWARD THE BLACK PRINCE}

Edward the Black Prince seems to have enjoyed good health up to 1366 (including his successful campaigns in France), and led an active, vigorous, and warlike life. His ill-health dates from his unfortunate expedition to Spain, undertaken to restore Don Pedro the Cruel to the throne of Castile. In 1366, when the Prince was at Valladolid waiting in vain for the promised money from King Pedro, "his army suffered so terribly from dysentery and other diseases that it is said that scarcely one Englishman out of five ever saw England again." "The army also were half-starved, and the free companions in the prince's pay ravaged the country."

The Prince contracted a severe and debilitating illness, which lasted for ten years. It was probably amoebic dysentery which merged into the chronic form, for there are contemporary references to his dysentery subsequently. Sir George McRobert informs me that amoebic dysentery still occurs in Spain as well as the bacillary forms. In 1369, when the Prince was at war with Charles $V$ of France, Froissart states that his health was so feeble that he could not take an active part: he was swollen with dropsy and could not ride. Oedema of the legs and ascites have been noted in dysentery due to anaemia caused by intestinal haemorrhage. Alternatively, the Prince's dropsy may have been due to chronic nephritis, which sometimes complicates dysentery. A third suggestion is that it was a "hunger oedema," due to semi-starvation in Spain. The first explanation seems the most probable one.

In 1370 Charles $\mathrm{V}$ of France raised armies for the invasion of Aquitaine. Though ill, the Prince left his sick bed in Angoulême, gathered an army at Cognac, and sacked Limoges. A sick man, he was carried in a litter.

In January, 1371, on the advice of his physicians, he returned to England and went to his manor of Berkhampstead " ruined in health and fortune." His health improved, presumably with rest and dieting. In August, 1372, he sailed on an expedition with King Edward III, his father, to relieve Thouars, but the fleet, exposed to contrary winds for nine weeks, eventually returned without landing on the French coast.

Later, "the Prince's sickness became very heavy." He knew he was dying, was much in prayer, and did many good and charitable works. "His dysentery became very violent, and he often fainted from weakness, so that his household believed he was actually dead." 34

This was the result of the severe dysenteric haemorrhages and associated weakness and anaemia.

The Prince eventually died from dysentery and exhaustion in 1376, aged 46. His body was brought from the Palace of Westminster to Canterbury and buried with great state in the Cathedral.

Arthur S. MacNalty.

${ }^{1}$ Knighton, H. In Historiae Anglicanae Scriptores Decem, edited by R.'Trysden, col. 2629. London, 1652

Chronicon Angliae, pref. XXIX, p. 88. London, 1874

3 Chandos, the Herald. Le Prince Noir, edited by F. Michel, line 4133. London, 1883

'Hunt, W. Dictionary of National Biography, vol. 17. 1889.

In her Annual Report for the year 1953 Dr. Catherine B. Crane, medical officer of health of the city of York, reports that attendances at the antenatal clinics, apart from midwives' clinics, were negligible, because the major part of the antenatal work in York is carried out by the patient's own doctor in domiciliary cases and by the hospital staff in cases booked for hospital confinement. "This we welcome," Dr. Crane writes, " provided adequate antenatal teaching can be given." 